\title{
EFEKTIVITAS MODEL PEMBELAJARAN KOOPERATIF TIPE JIGSAW TERHADAP KEMAMPUAN PENALARAN ALJABAR SISWA SMA
}

\author{
Sadikin $^{1 *}$, Rezky Agung Herutomo ${ }^{1}$ \\ ${ }^{1}$ Universitas Lakidende, Jl Sultan Hasanuddin No 234, Konawe-Sultra \\ *E-mail: sadikin_pmat13@yahoo.com
}

\begin{abstract}
Abstrak
Penelitian ini bertujuan untuk mendeskripsikan kemampuan penalaran aljabar siswa sebelum dan setelah pembelajaran serta mengetahui efektivitas model pembelajaran kooperatif tipe jigsaw terhadap kemampuan penalaran aljabar siswa. Desain penelitian ini adalah one group pretestposttest design. Populasi penelitian ini adalah seluruh siswa kelas X SMA Negeri 11 Kendari yang terdiri dari dua kelas paralel. Sampel penelitian diambil secara simple random sampling dan diperoleh kelas X-MIA 1 sebagai kelas eksperimen dengan jumlah sebanyak 30 orang. Data dianalisis secara deskriptif dan inferensial dengan uji-t pada taraf signifikansi 0,05. Hasil penelitian menunjukkan bahwa: (1) Kemampuan penalaran aljabar siswa sebelum pembelajaran belum mencapai ketuntasan klasikal dimana nilai rata-rata yang diperoleh hanya mencapai 36,17 ; (2) Kemampuan penalaran aljabar siswa setelah pembelajaran telah mencapai ketuntasan klasikal dimana nilai rata-rata yang diperoleh mencapai 82,83; dan (3) Model pembelajaran kooperatif tipe jigsaw efektif diterapkan dalam pembelajaran matematika untuk mendukung kemampuan penalaran aljabar siswa.
\end{abstract}

Kata kunci: penalaran aljabar, pembelajaran kooperatif, jigsaw

\section{PENDAHULUAN}

Aljabar merupakan salah satu cabang matematika, namun penguasaan konsep, proses, dan penalaran aljabar diperlukan dalam semua konten kurikulum pembelajaran matematika (Van de Walle, et al., 2013: 259). Karakteristik pola pikir dan penalaran aljabar merupakan salah satu isu yang banyak diteliti dalam bidang pendidikan matematika, karena diharapkan dapat mendukung kemampuan penalaran siswa diberbagai level pendidikan (Godino, et al., 2015: 426). Bahkan Cai dan Knuth (2005: 1) menyatakan bahwa kemampuan aljabar merupakan salah satu "gerbang" dalam pendidikan matematika.

Pernyataan di atas tidaklah berlebihan, mengingat penguasaan kemampuan penalaran aljabar memang sangat penting. Kemampuan penalaran aljabar akan membantu siswa dalam mempelajarimateri yang melibatkan aljabar. Misalnya pada saat belajar persamaan, pertidaksamaan, sistem persamaan, fungsi, persamaan garis, persamaan kuadrat, persamaan lingkaran, persamaan trigonometri, integral, turunan, dan materi lainnya yang membutuhkan penguasaan konsep aljabar.

Penalaran dan pola pikir aljabar dibentuk pemahaman siswa mengenai simbol (Van de Walle, et al., 2013: 259). Penalaran aljabar merupakan suatu proses dimana siswa menggeneralisasi ide-ide matematika dari sekumpulan contoh kasus, membuat generalisasi melalui argumentasi dan mengekspresikannya secara formal bergantung pada level usia siswa (Kaput dan Blanton, 2005: 99). Lebih lanjut Kaput (2008: 7) menyatakan ada dua aspek penting dalam penalaran aljabar, yaitu (1) membuat bentuk generalisasi secara 
formal berdasarkan sistem penyimbolan, dan (2) penalaran yang memuat manipulasi simbolik.

Level penalaran aljabar menurut Godino, et al. (2015: 427) didasarkan pada munculnya objek aljabar, penerapan operasi berdasarkan sifat-sifat strukturnya, dan penggunaan bahasa. Kaput (2008: 7) menyatakan ada tiga cabang dalam penalaran aljabar yang berfokus pada generalisasi dan simbolisasi, yaitu (1) kajian tentang struktur sistem bilangan (aljabar merupakan generalisasi aritmetika), (2) kajian tentang pola, hubungan, dan fungsi, dan (3) proses pemodelan matematika. Berdasarkan tiga cabang tersebut Van de Walle, et al. (2013: 259-281) mengembangkannya menjadi beberapa dimensi penalaran aljabar, diantaranya generalisasi aritmetika, penggunaan simbol yang bermakna, struktur sistem bilangan, kajian tentang pola dan fungsi, dan pemodelan matematika. Namun faktanya, dalam pembelajaran masih ditemukan kendala yang berkaitan dengan kemampuan aljabar. Herutomo (2017: 4) melaporkan bahwa siswa gagal dalam proses transisi dari aritemtika menuju aljabar, yang mengakibatkan penalaran siswa hanya terbatas pada pola induktif. Di sisi lain keabstrakan aljabar merupakan salah satu alasan yang menyebabkan terjadinya kendala dalam penguasaan penalaran aljabar (Breiteig dan Grevholm, 2006: 226).

Hal tersebut juga terjadi pada siswa kelas X-MIA 1 SMA 11 Kendari. Berdasarkan hasil studi pendahuluan yang dilakukan diketahui bahwa ketuntasan klasikal siswa belum mencapai 85\%. Pembelajaran belum mengarahkan siswa untuk dapat menggunakan penalarannya dalam menyelesaikan soal-soal matematika yang diberikan. Kemampuan siswa masih rendah dalam setiap dimensi kemampuan penalaran aljabar. Dari 5 butir soal tes awal yang diberikan, dimana skor ideal setiap dimensi adalah 4, diperoleh persentase skor untuk dimensi generalisasi dari aritmetika dan pola sebesar 59,17\%, persentase skor untuk dimensi menggunakan simbol sebesar $35,00 \%$, persentase skor untuk dimensi pembelajaran tentang struktur dan sistem bilangan sebesar 38,33\%, persentase skor untuk dimensi pembelajaran tentang pola, fungsional dan persamaan sebesar 37,50\%, dan persentase skor untuk dimensi pemodelan matematika sebesar 10,83\%. Ketuntasan klasikal siswa hanya mencapai persentase sebesar $36,17 \%$. Kondisi tersebut memerlukan perhatian khusus agar kemampuan penalaran aljabar siswa dapat meningkat sehingga berdampak pada hasil dan prestasi belajar siswa yang maksimal khususnya pada pelajaran Matematika.

Problematika tersebut tentunya memerlukan perhatian khusus dan perlu upaya untuk mendorong siswa menjadi pebelajar aktif sehingga dapat mengembangkan kemampuan penalaran aljabarnya. Guru harus membiasakan diri untuk menerapkan strategi atau cara membelajarkan siswa secara aktif agar proses pembelajaran dapat berjalan dengan baik sehingga tujuan kurikulum dapat tercapai. Fahinu (2007: 3) menyatakan pembelajaran matematika diharapkan dapat mengasah siswa agar memiliki kompetensi dasar di dalam matematika yaitu pada pemahaman, pemecahan masalah, penalaran, dan komunikasi matematik.

Proses pembelajaran yang mengaktifkan siswa tidak terlepas dari model pembelajaran yang digunakan.Jika dikaitkan dengan kemampuan siswa yang akan digali dalam pembelajaran, diduga bahwa melalui penerapan model pembelajaran kooperatif tipe jigsaw akan meningkatkan kemampuan penalaran aljabar siswa. Ketika siswa saling 
mendiskusikan masalah-masalah matematika dengan temannya atau kelompoknya, secara otomatis siswa akan lebih mudah menemukan serta memahami konsep-konsep yang rumit.

Beberapa keuntungan dari penerapan model kooperatif tipe jigsaw menurut Adams (2013: 65) antara lain (1) guru bukan lagi satu-satunya penyedia informasi pengetahuan bagi siswa, (2) siswa sendiri berperan sebagai pebelajar aktif sehingga proses pembelajaran lebih efisien, dan (3) mendorong interaksi antar siswa untuk mengembangkan keterampilan interaktif dan intra personal. Keuntungan lainnya seperti dikemukakan oleh Tran dan Lewis (2012: 9) bahwa model kooperatif jigsaw mendorong sikap positif siswa dalam pembelajaran matematika, kepercayaan diri, dan keterampilan belajar.

Hal tersebut sejalan dengan beberapa penelitian terdahulu yang terkait dengan model pembelajaran kooperatif tipe jigsaw. Hasil penelitian Sugianto, dkk (2014: 96) menyimpulkan bahwa keseluruhan siswa yang belajar dengan tipe pembelajaran kooperatif tipe jigsaw secara signifikan lebih baik dalam meningkatkan kemampuan penalaran matematika dan komunikasi matematika daripada siswa yang belajar dengan tipe kooperatif tipe STAD. Sejalan dengan itu, Astuti dan Abadi(2015: 248) dalam penelitiannya memberikan kesimpulan bahwa pembelajaran matematika dengan model pembelajaran kooperatif tipe jigsaw efektif ditinjau dari kemampuan penalaran dan sikap belajar matematika siswa. Hasil penelitian lainnya menunjukkan bahwa model pembelajaran jigsaw berkontribusi pada retensi pengetahuan siswa (Tran dan Lewis, 2012: 9), siswa yang mengikuti pembelajaran model jigsaw menunjukkan kinerja matematik yang lebih baik dibanding siswa yang mengikuti pembelajaran tradisional (Naomi dan Githua, 2013: 177).

Penerapan model pembelajaran kooperatif tipe jigsaw, siswanya dibagi berkelompok dengan 5 sampai 6 orang anggota kelompok belajar heterogen. Kelompok ini disebut kelompok asal. Setiap anggota kelompok bertanggung jawab untuk mempelajari bahantertentu yang diberikan oleh guru. Anggota dari kelompok lain yang mendapatkan tugas dan topik yang sama berkumpul dan membentuk kelompok ahli untuk membahas dan mendiskusikan topik tersebut. Selanjutnya masing-masing anggota dari tim ahli kembali ke kelompok asal untuk mengajarkan apa yang telah dipelajarinya.

Berdasarkan uraian tersebut, diperlukan adanya upaya nyata yang tepat agar kemampuan penalaran aljabar siswa dapat tumbuh dan berkembang sesuai dengan potensi siswa masing-masing. Pembelajaran kooperatif akan lebih bermakna dan membuat anggota kelompok bersemangat untuk belajar manakala pada setiap akhir kegiatan diikuti dengan sebuah tes atau tugas. Dengan tes antar kelompok atau individu diharapkan akan menumbuhkan sikap kompetitif antar kelompok sehingga setiap anggota dalam kelompok termotivasi untuk senantiasa bertanggungjawab atas keberhasilan kelompoknya.

Penelitian ini bertujuan untuk mendeskripsikan kemampuan penalaran aljabar siswa sebelum dan setelah pembelajaran serta untuk mengetahui efektivitas model pembelajaran kooperatif tipe jigsaw terhadap kemampuan penalaran aljabar siswa. Langkah-langkah model pembelajaran kooperatif tipe jigsaw meliputi(1)guru menjelaskan kepada seluruh siswa tentang akan diterapkannya model pembelajaran kooperatif tipe jigsaw, sebagai suatu variabel model pembelajaran serta guru menjelaskan kepada siswa tentang pola kerja sama, (2) para siswa dibagi dalam kelompok-kelompok kecilheterogen (kelompok asal) dimana setiap kelompok diberi lembar kerja siswa tertentu untuk dikerjakan, (3) ketua 
kelompok membagi tugas yang diberikan untuk dikerjakan oleh masing-masing anggota kelompok (misalnya, setiap siswa dalam kelompok mendapat 1 soal yang berbeda), (4) dari beberapa kelompok asal yang telah terbentuk, anggota kelompok yang mendapat soal yang sama bertemu dan membuat kelompok baru (kelompok ahli) untuk mendiskusikan soal tersebut, (5) kemudian siswa kembali ke kelompok asalnya dan bergantian menjelaskan hasil penyelesaian soal kepada anggota dalam kelompok asal, dan (6) guru beserta siswa siswa membahas hasil diskusi kelompok sehingga memperoleh suatu kesimpulan (Djumaliningsih, dkk. 2012: 123). Dimensi kemampuan penalaran aljabar pada penelitian ini dikembangkan dari Van de Walle, et al. (2013: 259-281) yang meliputi generalisasi dari aritmatika dan pola-pola, menggunakan simbol untuk variabel kuantitas, kajian tentang struktur (pola dan keteraturan) dan sistem bilangan, kajian tentang pola, fungsional, grafik atau persamaan, dan pemodelan struktur matematika dari situasi di dalam atau di luar konteks matematika.

\section{METODE}

Penelitian eksperimen ini dilaksanakan di SMA Negeri 11 Kendari pada semester genap Tahun Ajaran 2017/2018 yang terdiri dari dua kelas. Penelitian ini menggunakan one group pretest-posttest design. Teknik sampling yang digunakan adalah simple random sampling, diperoleh satu kelas eksperimen yaitu kelas X-MIA1 dengan jumlah siswa 30 orang. Penelitian ini tidak menggunakan kelas kontrol. Variabel dalam penelitian ini terdiri dari satu variabel bebas yaitu model pembelajaran kooperatif tipe jigsaw dan satu variabel terikat yaitu kemampuan penalaran aljabar siswa. Untuk memperoleh data dalam penelitian ini digunakan instrumen penelitian berupa tes tertulis dalam bentuk uraian. Data dalam penelitian ini diperoleh melalui nilai hasil kerja siswa pada tes awal (pretest) sebelum penerapan model pembelajaran kooperatif tipe jigsaw pada materi SPLDVserta nilai hasil kerja siswa pada tes akhir (posttest) setelah penerapan model pembelajaran kooperatif tipe jigsaw pada materi SPLTV. Jumlah soal yang digunakan untuk pretest maupun posttest adalah sebanyak 5 nomor yang mewakili masing-masing dimensi penalaran aljabar siswa.

Penelitian eksperimen ini menggunakan dua teknik analisis data yakni analisis deskriptif dan analisis inferensial. Analisis deskriptif dimaksudkan untuk menggambarkan keadaan sampel dalam bentuk persentase, rata-rata, median, modus, standar deviasi, varians, nilai maksimum, nilai minimum, dan untuk menggambarkan tingkat kemampuan penalaran aljabar siswa dalam bentuk kualitatif. Analisis Inferensial merupakan analisis yang digunakan untuk menguji hipotesis penelitian, namun terlebih dahulu melalui tahapan uji normalitas menggunakan statistik uji Kolmogorov-Smirnov sebagai uji prasyarat untuk melakukan uji hipotesis. Jika data penelitian berdistribusi normal, maka untuk menguji hipotesis efektivitas model pembelajaran kooperatif terhadap kemampuan penalaran aljabar, digunakan statistik uji-t sampel berpasangan (paired sample t-test) dengan bantuan aplikasi SPSS.

\section{HASIL}

Hasil penelitian ini mendukung hipotesis yang diajukan yaitu model pembelajaran kooperatif tipe Jigsaw efektif diterapkan dalam pembelajaran matematika terhadap kemampuan penalaran aljabar siswa.Hasil analisis deskriptif data kemampuan penalaran 
aljabar siswa antara sebelum (pretest) dan setelah (posttest) penerapan model pembelajaran kooperatif tipe jigsaw ditunjukkan pada Tabel 1 berikut.

Tabel 1. Hasil Analisis Deskriptif Pretest dan Posttest Kemampuan Penalaran Aljabar

\begin{tabular}{cccc}
\hline No. & Statistik & Pretest & Posttest \\
\hline 1 & $n$ & 30 & 30 \\
\hline 2 & Mean & 36,17 & 82,83 \\
\hline 3 & Median & 37,50 & 85,00 \\
\hline 4 & Mode & 30 & 90 \\
\hline 5 & Std. Deviation & 14,00 & 11,65 \\
\hline 6 & Variance & 196,06 & 135,66 \\
\hline 7 & Minimum & 10 & 50 \\
\hline 8 & Maximum & 65 & 100
\end{tabular}

Tabel 1 menunjukkan perbedaan rata-rata kemampuan penalaran aljabar siswa sebelum dan setelah pembelajaran. Pembelajaran yang diberikan mampu meningkatkan kemampuan penalaran aljabar siswa dari nilai rata-rata 36,17 menjadi 82,83. Distribusi data pretest dan posttest yang menggambarkan kategori ketuntasan kemampuan penalaran aljabar siswa secara kualitatif dapat dilihat pada Tabel 2 dan Tabel 3 berikut.

Tabel 2. Distribusi Data Pretest

\begin{tabular}{ccccc}
\hline No. & Nilai/Kriteria & Kkategori & Frekuensi & Persentase (\%) \\
\hline 1 & $x \geq 65$ & Tuntas & 1 & 3,33 \\
\hline 2 & $x<65$ & Tidak Tuntas & 29 & 96,67 \\
\hline & Jumlah & & 30 & 100 \\
\hline
\end{tabular}

Tabel 3. Distribusi Data Posttest

\begin{tabular}{ccccc}
\hline No. & Nilai/Kriteria & Kategori & Frekuensi & Persentase(\%) \\
\hline 1 & $x \geq 65$ & Tuntas & 28 & 93,33 \\
\hline 2 & $x<65$ & Tidak Tuntas & 2 & 6,67 \\
\hline & Jumlah & & 30 & 100 \\
\hline
\end{tabular}

Tabel 2 menunjukkan dengan kriteria ketuntasan minimal sebesar 65 diperoleh hanya 1 atau 3,33\% siswa yang telah mencapai ketuntasan minimal dan 29 atau 96,67\% siswa belum mencapai ketuntasan. Pada Tabel 3 menunjukkan 28 atau 93,33\% siswa telah mencapai ketuntasan dan hanya 2 atau 6,67\% siswa yang belum mencapai ketuntasan.

Nilai rata-rata dan peningkatan rata-rata tiap dimensi kemampuan penalaran aljabar siswa sebelum dan setelah penerapan pembelajaran kooperatif tipe jigsaw dapat dilihat pada Tabel 4 berikut. 
Tabel 4. Nilai Rata-rata dan Peningkatan Rata-rata Dimensi Penalaran Aljabar

\begin{tabular}{clccc}
\hline No. & \multicolumn{1}{c}{ Dimensi } & Pretest & Posttest & N-Gain \\
\hline 1 & $\begin{array}{l}\text { Generalisasi dari } \\
\text { aritmetika dan pola }\end{array}$ & 2,37 & 3,80 & 0,88 \\
\hline 2 & Menggunakan simbol & 1,40 & 3,50 & 0,81 \\
\hline & $\begin{array}{l}\text { Pembelajaran tentang } \\
\text { struktur dan sistem } \\
\text { bilangan }\end{array}$ & 1,53 & 3,27 & 0.70 \\
\hline 4 & $\begin{array}{l}\text { Pembelajaran tentang } \\
\text { pola, fungsional, dan } \\
\text { persamaan }\end{array}$ & 1,50 & 3,17 & 0,67 \\
\hline 5 & Pemodelan matematika & 0,43 & 2,83 & 0,67 \\
\hline
\end{tabular}

Tabel 4 menunjukkan nilai rata-rata tiap dimensi kemampuan penalaran aljabar sebelum pembelajaran dimana dimensi generalisasi dari aritmetika dan pola memperoleh nilai tertinggi yaitu 2,37. Dimensi pemodelan matematika memperoleh nilai terendah yaitu 0,43 . Untuk nilai rata-rata tiap dimensi kemampuan penalaran aljabar setelah pembelajaran dimana dimensi generalisasi dari aritmetika dan pola memperoleh nilai tertinggi yaitu 3,80. Dimensi pemodelan matematika memperoleh nilai terendah yaitu 2,83 . Selanjutnya pada nilai $\mathrm{N}$-Gaindimensi generalisasi dari aritmetika dan pola menunjukkan peningkatan ratarata tertinggi yaitu sebesar 0,88. Dimensi pembelajaran tentang pola, fungsional, dan pola serta dimensi pemodelan matematika menunjukkan peningkatan rata-rata terendah yaitu sebesar 0,67.

Hipotesis "model pembelajaran kooperatif tipe jigsaw efektif diterapkan dalam pembelajaran matematika untuk mendukung kemampuan penalaran aljabar siswa"dalam penelitian ini digunakan uji-t sampel berpasangan (paired sample t-test) dengan asumsi normalitas data telah terpenuhi. Hasil analisis data dengan bantuan SPSS dapat dilihat pada Tabel 5 berikut.

Tabel 5. Hasil Uji Hipotesis

\begin{tabular}{lccc}
\hline & \multicolumn{3}{c}{ Statistik } \\
\cline { 2 - 4 } Pair 1 Posttest-Pretest & $\mathbf{t}$ & $\mathbf{d f}$ & Sig. (2-tailed) \\
\cline { 2 - 4 } & 19,34 & 29 & 0,00 \\
\hline
\end{tabular}

Tabel 5 menunjukkan nilai t hitung sebesar 19,34 > t tabel $(1,70)$ dan nilai signifikansi Sig. (2-tailed) sebesar 0,00 <0,05, maka Ho ditolak. Dengan ditolaknya Ho dapat disimpulkan bahwa model pembelajaran kooperatif tipe jigsaw efektif diterapkan dalam pembelajaran matematika untuk mendukung kemampuan penalaran aljabar siswa pada materi SPLTV dengan taraf kepercayaan $95 \%$.

\section{PEMBAHASAN}

Peningkatan kemampuan penalaran aljabar siswa tergolong sangat baik karena setelah pembelajaran 93,33\% siswa telah mencapai ketuntasan minimum. Distribusi data pretest dan posttest dalam penelitian dapat memberikan gambaran deskriptif bahwa model 
pembelajaran kooperatif tipe jigsaw efektif diterapkan dalam pembelajaran matematika untuk mendukung kemampuan penalaran aljabar siswa.

Analisis data secara deskriptif dan inferensial terhadap data penelitian telah menunjukkan adanya peningkatan rata-rata kemampuan penalaran aljabar siswa baik secara umum maupun berdasarkan setiap dimensi kemampuan penalaran aljabar. Terjadinya peningkatan kemampuan penalaran aljabar siswa ini disebabkan oleh penggunaan model pembelajaran kooperatif tipe jigsaw. Berdasarkan observasi pada proses pembelajaran kooperatif tipe jigsaw, siswa lebih konsentrasi sehingga kualitas aktivitas belajarnya menjadi lebih baik. Kegiatan diskusi baik dalam kelompok maupun diskusi kelas siswa unggul dapat membantu siswa lemah dari sisi penguasaan materi. Siswa lemah juga mampu mengeluarkan ide-idenya dan berani bertanya balik pada setiap sesi diskusi. Siswa unggul mampu menyampaikan gagasannya secara sistematis dan terukur sehingga mudah dipahami oleh teman-temannya. Hal ini disebabkan karena pembelajaran kooperatif tipe jigsaw menuntut siswa untuk berperan aktif sehingga mampu mendorong siswa untuk dapat mengembangkan kemampuan penalarannya dalam memecahkan setiap masalah matematika.

Bila ditinjau dari kemampuan penalaran aljabar pada Tabel 4, diketahui bahwa hasil yang diperoleh mengalami peningkatan.Peningkatan yang terjadi menunjukkan bahwa model pembelajaran kooperatif tipe jigsaw mendukung kemampuan penalaran aljabar siswa.Melalui pembelajaran tersebut siswa dilatih untuk menggunakan dimensi-dimensi penalaran aljabar dalam pembelajaran. Terlebih lagi dalam pemecahan masalah bersama kelompok ahli, sebagaimana yang dikemukakan oleh Naomi dan Githua (2013: 179) bahwa siswa yang terlibat dalam tugas-tugas yang menantang dalam masing-masing kelompok ahli sangat berantusias, sebab para siswa tahu bahwa informasi-informasi dalam kelompok ahli harus disampaikan ketika siswa kembali ke kelompoknya masing-masing. Jadi dengan adanya tugas tersebut, siswa punya tanggung jawab untuk berbagi pengetahuan berkaitan dengan dimensi penalaran aljabar yang digunakan dalam pemecahan masalah kepada teman kelompoknya.

Pendapat guru secara umum mengenai pembelajaran matematika dengan model kooperatif tipe jigsaw adalah positif. Namun demikian, masih ada kelemahan yang perlu diperbaiki diwaktu mendatang. Kelemahan yang dimaksud terutama adalah karena siswa tidak terbiasa belajar di kelas dengan model pembelajaran kooperatif tipe jigsaw sehingga perlu waktu yang cukup untuk membiasakannya pada siswa. Keunggulan dan kelemahan suatu model pembelajaran yang diterapkan penting diketahui untuk tercapainya tujuan pembelajaran.

Fakta yang terdapat dalam penelitian ini adalah model pembelajaran kooperatif tipe jigsaw dapat diterapkan dan dijadikan sebagai salah satu alternatif untuk membantu siswa dalam meningkatkan kemampuan penalaran aljabarnya.Kemampuan penalaran aljabar yang baik merupakan salah satu modal bagi siswa untuk sukses dalam belajar matematika.

\section{KESIMPULAN DAN SARAN}

Kesimpulan yang dapat dikemukakan dalam penelitian adalah sebagai berikut yaitu: (1) Kemampuan penalaran aljabar siswa sebelum pembelajaran belum mencapai ketuntasan klasikal dimana nilai rata-rata yang diperoleh hanya mencapai 36,17 ; (2) 
Kemampuan penalaran aljabar siswa setelah pembelajaran telah mencapai ketuntasan klasikal dimana nilai rata-rata yang diperoleh mencapai 82,83; dan (3) Model pembelajaran kooperatif tipe jigsaw efektif diterapkan dalam pembelajaran matematika untuk mendukung kemampuan penalaran aljabar siswa.

Saran yang dapat dikemukakan dalam penelitian ini adalah sebagai berikut yaitu: (1) Untuk guru-guru bidang studi matematika, pembelajaran dengan model kooperatif tipe jigsaw dapat dijadikan sebagai alternatif dalam pembelajaran matematika untuk meningkatkan kemampuan penalaran aljabar siswa SMA, khususnya materi sistem persamaan linear tiga variabel, dan (2) Untuk peneliti selanjutnya, disarankan mengkaji aspek lain yang belum terjangkau dalam penelitian ini seperti kreativitas siswa dalam penalaran aljabar dan aktivitas guru selama pembelajaran dengan menggunakan model pembelajaran kooperatif tipe jigsaw.

\section{DAFTAR PUSTAKA}

Adams, F.H. 2013. Using jigsaw technique as an effective way of promoting cooperative learning among primary six pupils in Fijai. International Journal of Education and Practice, 1(6), 64-74.

Astuti, R.D., \& Abadi, A.M.2015. Keefektifan pembelajaran jigsaw dan TAI ditinjau dari kemampuan penalaran dan sikap belajar matematika siswa. Jurnal Riset Pendidikan Matematika,2 (2), 235-250.

Breiteig, T. \& Grevholm. 2006. The transition from arithmetic to algebra: to reason, explain, argue, generalize and justify. In J. Novotná, H. Moraová, M. Krátká, \& N. Stehlíková (Eds.). Proceedings 30th Conference of the International Group for the Psychology of Mathematics Education, 225-232. Prague: PME.

Cai, J. \& Knuth, E.J. 2005. The development of students' algebraic thinking in earlier grades from curricular. instructional and learning perspectives. ZDM, 37(1), 1-4.

Djumaliningsih, N.P., Riyadi, \& Iswahyudi, G. 2012. Eksperimentasi model pembelajaran kooperatif tipe jigsaw yang berorientasi pada penemuan terbimbing dengan penggunaan alat peraga pada materi bangun datar segi empat ditinjau dari kemampuan penalaran matematika. Journal of Mathematics and Mathematics Education, 2 (2), 120-135.

Fahinu. 2007. Meningkatkan kemampuan berpikir kritis dan kemandirian belajar matematika pada mahasiswa melalui pembelajaran generatif. Disertasi, tidak dipublikasikan.Universitas Pendidikan Indonesia.

Godino, J.D., Neto, T., Wilhelmi, M.R., Ake, L., Etchegaray, S., \& Lasa, A. 2015. Levels of algebraic reasoning in primary and secondary education.In Krainer, \& Vondrova (Eds.). Proceedings of the Ninth Confrence of the European Society for Research in Mathematics Education, 426-432. Prague: Charles University in Prague.

Herutomo, R.A. 2017. Miskonsepsi aljabar: konteks pembelajaran matematika pada siswa kelas VIII SMP. Journal of Basication: Jurnal Pendidikan Dasar, 1(1), 1-8.

Kaput, J., \& Blanton, M. 2005. Algebrafying the elementary mathematics experience in a teacher-centered, systemic way.In T. Romberg \& T. Carpenter 
(Eds.).Understanding mathematics and science matters (99-125). Mahwah, NJ: Lawrence Erlbaum Associates.

Kaput, J.J. 2008. What is algebra? What is algebraic reasoning? In Kaput, Carraher, \& Blanton (Eds.).Algebra In The Early Grades, 5-18. New York: Lawrence Erlbaum Associates.

Naomi, M.W. \& Githua, B.N. 2013. Effects of jigsaw cooperative learning strategy on students' achievement in secondary school mathematics in Laikipia East District, Kenya. Asian Journal of Management Sciences and Education, 2(3), 177-188.

Sugianto, Armanto, D., \& Harahap, M.B.2014. Perbedaan penerapan model pembelajaran kooperatif tipe jigsaw dan STAD ditinjau dari kemampuan penalaran dan komunikasi matematis siswa SMA . Jurnal Didaktik Matematika, 1 (1), 96-128.

Tran, V.D. \& Lewis, R. 2012. The effects of jigsaw learning on students' attitudes in a vietnamese higher education classroom. International Journal of Higher Education, $1(2), 9-20$.

Van de Walle, Karp, K.S., \& Bay-Williams. 2013. Elemetary and middle school mathematics teaching developmentally. New Jersey: Pearson Education, Inc. 